\title{
Achieving Water Security
}

\author{
Prof. Frank Rijsberman ${ }^{6}$
}

Your Excellencies, Ladies and Gentlemen,

The International Water Management Institute (IWMI) is very pleased to be a coorganizer, with ESCAP, ADB and the Royal Thai Government, of this important policy Dialogue that brings together, for the first time, high-level water policymakers from ten Asian countries. I believe that this is particularly an opportune moment for this meeting. As you are all too aware in this audience, there are very serious water-related issues in the region that require considerable investments as well as innovative solutions. International cooperation can contribute to both increased awareness of the water issues outside the water sector-needed to increase investments in the sector-and sharing of information and experience that will contribute to finding and applying innovative solutions. It is quite fortunate that, currently, there is a significantly increasing interest and attention for water issues in the world, at the national and international level. There are several very important opportunities ahead to increase awareness of Asian water issues. In August, the Government of South Africa will host the UN's World Summit on Sustainable Development in Johannesburg, and next year in March, the Government of Japan will host the $3^{\text {rd }}$ World Water Forum in Kyoto.

Ten years ago, water was not at the top of the agenda in Rio, but I would argue that it should be in Johannesburg. The 2nd World Water Forum, held in The Hague in March 2000, put the world water crisis squarely on the international agenda. Over 5,000 water stakeholders, including more than 100 ministers and 600 journalists, came together to call the world's attention to the many urgent water issues.

Today's water crisis is mostly about access to safe and affordable drinking water, while tomorrow's water crisis is likely to see the rising importance of other forms of water scarcity and water stress affecting much more than water for drinking. People in the worst-off 50 countries today must try and meet all their water and sanitation needs on an average of 30 liters or less per day, far less than the 50-liter per day level that, the United Nations says, constitutes the absolute minimum for water needs. Incredibly, people in 13 countries must try and live on an average of less than 10 liters per day, a truly desperate situation. People who live on less than 10 liters of water per day can never escape poverty and cannot achieve sustainable development without first addressing their water scarcity.

Water is crucial to development. This can be seen by the fact that while the world population tripled in the twentieth century, the use of renewable water resources grew sixfold, mostly for use in agriculture. We have seen that no single type of intervention has had greater overall impact upon economic development and public health than the provision of safe drinking water and proper sanitation. In health alone, improved water and sanitation can reduce morbidity and mortality rates of some of the most serious of water-related diseases by up to 80 percent.

${ }^{6}$ Director General, International Water Management Institute.

f.rijsberman@cgiar.org,www.iwmi.org 
I know that there will be many, many issues competing for attention at the Johannesburg Summit and there is a risk that attention will be so divided that concrete results are difficult to achieve. It is therefore important to focus the attention clearly on a small number of priority issues, and recommend a small number of high-priority actions.

The UN Secretary General, Mr. Kofi Annan, has invited 12 people to help him prepare the Johannesburg Summit and, among these, the Dutch Crown Prince, the Prince of Orange, that many of you know as the Chair of the 2nd World Water Forum, has prepared a contribution that focuses specifically on water. The document was distributed here this morning and I would like to introduce to you its key recommendations. If the international community would focus on a small number of priority targets and actions and, more importantly, make a significant commitment to achieve these, it could, in my view, go a long way towards solving the water crisis at the global level. I propose these recommendations here for your consideration later this morning.

The targets and actions are organized in the four key areas identified by the panel of the Secretary General as follows: 1) shared values, 2) the public-private sector nexus, 3) global governance, and 4) science and technology.

The three recommended targets on "shared values" start with the target adopted by the Millennium Conference on safe drinking water, and a similar target for sanitation and-I feel importantly-propose a new target focused on water for productive use. The targets are:

1. Halve the proportion of people who are unable to reach or to afford safe drinking water resources by 2015 .

2. Halve the proportion of people who are unable to reach or to afford sanitation by 2015.

3. Increase water productivity in agriculture (rain-fed and irrigated) to enable food security for all people without increasing water diverted for irrigated agriculture over that used in 2000.

The corresponding recommended action is to mandate the World Water Assessment Programme of the United Nations to establish a baseline, and monitor progress towards these targets and report to the Ministerial Conferences associated with the World Water Forum series or to the UN CSD.

Related to the public-private sector nexus, the recommended target is to have at least 20 percent of all water infrastructural investments funded by alternative forms of financing by 2015.

The corresponding action is to build capacity in local government to assess alternative forms of financing for infrastructure, including capacity to identify, develop and negotiate sound projects that are financially feasible and environmentally sustainable as alternative solutions to large-scale investments.

Concerning global governance the recommended target is to assess virtual water imports and exports through agricultural products for each country by 2015. In other words, to analyze the impacts of the changes in the subsidies in agriculture and the international system of trade in food and fiber on national and local water demands by 2015. 
It is recommended that in the international trade negotiations on agricultural subsidies and trade in agricultural products the World Trade Organization should consider the impact on water use in countries importing and exporting food.

Finally, related to science and technology my recommended target—among many other issues that are important and outlined in No Water, No Future-is to develop, by 2010, an agreed strategy for the use of molecular biology to increase drought tolerance and water productivity of crops to achieve water, food and environmental security. Please note that this recommendation does not imply support for genetically modified organisms. The improved understanding of the genomes of many organisms, and the availability of tools at the molecular level, enable us to advance in many directions, including for example marker-aided-selection that can help speed up traditional plant-breeding methods. The Prince of Orange proposes to develop a strategy that brings people together to capture the potential of these advances in science in a manner that is environmentally sustainable and socially acceptable.

The corresponding recommended action is to have the Consultative Group on International Agricultural Research, the CGIAR, assess the potential for increased drought tolerance and increased water productivity in agriculture, including the potential of the use of functional genomics and other tools of modern molecular biology.

The water crisis that is affecting so many people is mainly a crisis of governance-not of water scarcity. Overcoming the world water crisis-achieving water, food and environmental security simultaneously - is one of the most formidable challenges on the road to sustainable development. More and more people, organizations and governments are becoming aware of this challenge. The World Summit on Sustainable Development should reaffirm the importance of achieving water security and adopt targets and actions that will allow us to meet this challenge jointly.

IWMI has prepared a number of initiatives in our field as an international research organization, focusing on improving water- and land-resources management for food, livelihoods and nature, that we think will make a significant contribution to these targets I outlined to you. I am referring to an effort that is underway that we call the "Comprehensive Assessment of Water Management in Agriculture" and to a major new program that we are preparing that is called the CGIAR Challenge Program on Water and Food. Both these programs we think will contribute significantly to several of the targets mentioned above, particularly the target to improve water productivity in agriculture (rain-fed and irrigated) to enable food security for all people without increasing water diverted for irrigated agriculture over that used in 2000. These programs will offer an excellent opportunity to cooperate with many of the organizations that participate in this meeting to achieve the priorities that I hope will be expressed clearly at this meeting. At the same time, I recognize that this is only the first meeting of its kind in this region. I sincerely hope that it will be a very successful meeting that will be the start of a process of closer cooperation in the region on issues of water-resources management.

I thank you. 